\title{
TINJAUAN ATAS PERMASALAHAN PENEGAKAN HUKUM DAN PEMENUHAN HAK DALAM KONTEKS UNIVERSALIME DAN RELATIVISME HAK ASASI MANUSIA DI INDONESIA
}

\author{
Ridwan Arifin, Rasdi, Riska Alkadri \\ Fakultas Hukum, Universitas Negeri Semarang \\ Jl. Taman Siswa, Sekaran, Gunungpati, Semarang, 50229 \\ E-mail : ridwan.arifin@mail.unnes.ac.id, rasdi@mail.unnes.ac.id, riskaalkadri@gmail.com
}

\begin{abstract}
The four principles of freedom (four freedoms) include freedom of speech and expression, freedom of religion and belief, freedom from want, and freedom from fear, are basic principles recognized by countries and translated into many more specific forms of human rights fulfillment human. The fulfillment and protection of human rights is one indicator of the progress of a country. The scope of fulfilling human rights that covers a very broad field, from education, health, to law enforcement, is a challenge. The UN Security Council 2017 Universal Periodical Review (UPR) session provides recommendations for strengthening human rights in Indonesia, including the ratification of international human rights instruments, the continued cooperation of UN human rights, the abolition of the death penalty, matters related to sexual orientation and efforts to protect tolerance and diversity. The Commission for Missing Persons and Victims of Violence (Kontras) 2017 records 84 cases of violence and human rights violations that occurred. The issue of interpreting different human rights standards is one of the causes of this high problem in Indonesia. Many different interpretations are caused by the running of different political systems of state administration, causing the implementation of human rights fulfillment to be different. This paper looks at and compares the practices of human rights enforcement covering the four principles of freedom in Indonesia. This paper will compare the implementation of human rights standards and norms in national domestic practices based on international human rights principles and norms.
\end{abstract}

Keywords: Interpretation, Different Standard of Human Rights, Law Enforcement, Universalism and Relativism.

\begin{abstract}
Abstrak
Empat prinsip kebebasan (four freedoms) meliputi kebebasan berbicara dan bereskpresi, kebebasan beragama dan berkeyakinan, kebebasan dari kemiskinan, dan kebebasan dari rasa takut, merupakan prinsip dasar yang diakui oleh negara-negara dan diterjemahkan ke dalam banyak bentuk yang lebih spesifik dalam pemenuhan hak asasi manusia (HAM), salah satunya
\end{abstract}


hak-hak sipil, politik, ekonomi, sosial dan budaya. Pemenuhan dan perlindungan HAM menjadi salah satu indikator kemajuan dari sebuah negara. Ruang lingkup pemenuhan HAM yang mencakup bidang yang sangat luas, mulai dari pendidikan, kesehatan, sampai penegakan hukum, menjadi tantangan tersendiri. Sidang Universal Periodical Review (UPR) Dewan Keamanan PBB Tahun 2017 memberikan rekomendasi penguatan HAM di Indonesia meliputi ratifikasi instrumen HAM internasional, kerjasama lanjutan HAM PBB, penghapusan hukuman mati, hal berkaitan dengan orientasi seksual dan upaya perlindungan atas toleransi dan keberagaman. Komisi untuk Orang Hilang dan Korban Tindak Kekerasan (Kontras) 2017 mendata ada 84 kasus kekerasan dan pelanggaran HAM yang terjadi. Persoalan penafsiran standar HAM yang berbeda-beda menjadi salah satu penyebab tingginya permasalahan ini di Indonesia. Tafsiran yang berbeda tersebut banyak disebabkan oleh berjalannya sistem politik penyelenggaraan negara yang berbeda, hingga menyebabkan implementasi pemenuhan hak asasi manusia pun menjadi berbeda. Tulisan ini melihat dan membandingkan praktik penegakan HAM yang meliputi keempat prinsip kebebasan tersebut di Indonesia. Tulisan ini akan membandingkan pelaksanaan standar dan norma HAM dalam praktik domestik nasional berbadasarkan prinsip dan norma HAM internasional.

\section{Kata Kunci: Interpretasi, Standar Hak Asasi Manusia yang Berbeda, Penegakkan Hukum, Universalisme dan Relativisme.}

\section{A. PENDAhULUAN}

Paradigma penegakan hak asasi manusia (HAM), bukan hanya meliputi satu aspek yaitu perlindungan terhadap hak asasi saja melainkan ada tiga aspek penting dalam kerangka penghormatan (to respect), perlindungan (to protect), dan pemenuhan (to fulfill). Pelaksanaan atas penghormatan, perlindungan, dan pemenuhan hak asasi manusia haruslah sejalan dengan prinsip-prinsip universal hak asasi manusia yang diakui dan diadopsi oleh negara-negara dalam lingkup internasional. Meskipun faktanya, pelaksanaan dalam tataran domestik nasional, tiga aspek tersebut sangat dipengaruhi oleh konsep HAM yang diadopsi oleh negara, baik itu konsep universalime maupun relativisme. Praktik HAM universal, menurut Erik Posner, telah gagal gagal mencapai tujuannya. Alasannya bahwa hak asasi manusia tidak pernah universal seperti yang diharapkan orang, dan keyakinan bahwa mereka dapat dipaksakan atas negara-negara sebagai masalah hukum internasional ternyata menemui banyak masalah. ${ }^{1}$ Padahal, standar dan norma HAM secara internasional telah jelas dimuat dalam Dekalarasi Hak Asasi Manusia (Universal Declaration of Human Rights, UDHR) 1948

Erik Posner menegaskan bahwa persoalan demokrasi dan liberalisasi, dimana dalam praktik HAM secara internasional, banyak dipengaruhi oleh batasan pemahaman dari tiap-tipa negara. Menurutnya, misalnya, Amerika Serikat, menjadi salah satu penantang terberat dalam penegakan hukum HAM secara internasional. Baca Eric Posner, 2014, "The Case Againts Human Rights", The Guardian, 4 Desember 2014, diakses dari https://www.theguardian.com/news/2014/dec/04/-sp-case-against-human-rights 
dan telah diterima sebagai pandangan yang paling mendasar bagi hampir seluruh instrumen hukum Internasional dan dasar dalam pemenuhan hak asasi manusia.

Masalah-masalah tersebut tidak hanya terjadi dalam konteks UDHR yang universal, namun juga pada aturan turunan dari deklarasi tersebut. Misalnya, meskipun pengarusutamaan hak asasi manusia internasional juga diikuti oleh ratifikasi dua intrumen penting lainnya, yakni The International Covenant on Civil and Political Rights (ICCPR), dan The Covenant on Economic, Social and Cultural Rights (ECOSOC), namun faktanya masih banyak negara yang melakukan pelanggaran atas prinsip yang terkandung dalam instrumeninstrumen hukum tersebut dibandingkan upaya penghormatan, perlindungan, dan pemenuhan hak asasi manusia. Terlepas dari kenyataan bahwa hak asasi manusia secara definisi memiliki ruang lingkup yang universal, dimana semua hak yang diakui secara Internasional, termasuk perlindungan dan penghormatan terhadap orang-orang dengan kebutuhan khusus, namun pemenuhan hak asasi manusia masih menghadapi berbagai masalah. ${ }^{2}$ Bahkan, jauh sebelum UDHR 1948, prinsip kebebasan (four freedoms) ${ }^{3}$ sebagai menifestasi hak asasi manusia dianggap sebagai hal yang sangat penting. Namun keempat kebebasan ini juga masih menemukan permasalahan dalam penegakan hukum dan pemenuhannya hingga hari ini, tidak terkecuali di Indonesia.

Masalah yang sering timbul berkatan dengan pemenuhan hak asasi manusia dan juga penegakan hukumnya adalah ketidaksamaan standar dan norma yang diterjemahkan oleh masing-masing negara atau penyelenggara negara. Meskipun Jack Donnely ${ }^{4}$ mengatakan

United Nations Human Rights Office of the High Commissions menyoroti bahwa the Covenant on Economic, Social and Cultural Rights dan the International Covenant on Civil and Political Rights mencakup segala ketentuan yang sangat relevan untuk perlindungan hak asasi manusia orang yang lebih tua, seperti hak atas kesehatan, hingga standar hidup yang layak, kebebasan dari penyiksaan, kapasitas hukum dan persamaan di depan hukum. Instrumen lain, the Convention on the Elimination of All Forms of Discrimination against Women (CEDAW) dan the Convention on the Elimination of All Forms of Racial Discrimination (CERD) juga mengandung ketentuan yang berlaku untuk orang yang lebih tua dalam ruang lingkupnya yang relevan. The International Convention on the Protection of the Rights of Migrant Workers and the members of their families (ICMW), pasal 7, termasuk "usia" dalam daftar alasan yang dilarang untuk diskriminasi.

Lihat http://www.ohchr.org/EN/Issues/OlderPersons/IE/Pages/InternationalStandards.aspx

3 Franklin Delano Roosevelt menyebut empat kebebasan ini sebagai four essential human freedoms, yang meliputi: (1) freedom of speech and expression, (2) freedom of every person to worship God in his own way, (3) freedom from want, dan (4) freedom from fear. Lihat Franklin Delano Roosevelt, 1941, "The four freedoms", outlined in a speech on January 6, diakses dari http://maitreyasangha.org/wpcontent/uploads/2012-The-Four-Freedoms-UN-Charter.pdf; Nelson Tebbe, 2014, "Associations and the Constitution: Four Questions about Four Freedoms", The North Carolina Law Review, Vol. 92 No. 3, hlm. 917-947.

4 Jack Donnely, 2013, Universal Human Rights in Theory and Practice, Cornell University Press, New York, hlm. 10-11. 
secara tegas bahwa ak asasi manusia adalah hak yang setara (equal rights), baik ia seorang manusia atau bukan, dan karena itu memiliki hak asasi manusia yang sama seperti orang lain, hak asasi manusia juga merupakan hak yang tidak dapat dicabut (inalienable rights) dimana seseorang tidak dapat berhenti menjadi manusia, tidak peduli betapa buruknya perilaku seseorang atau bagaimana seseorang diperlakukan dengan kejam, dan itu adalah hak universal (universal rights), dalam arti bahwa saat berbicara hak asasi manusia, manusia menjadi objek an dengan demikian pemegang hak asasi manusia itu sendiri. Faktanya, kasus-kasus pelanggaran HAM baik dalam skala yang kecil maupun besar terus terjadi. Komisi Nasional Hak Asasi Manusia (Komnas HAM) tahun $2016^{5}$ merilis ada 7.188 berkas kasus pengaduan atas pelanggaran HAM di seluruh Indonesia, dan jumlah terbanyak dalam kasus tersebut pada sektor penegakan hukum (2.697) dan kesejahteraan (2.748). Jumlah tersebut terus meningkat dan data pada Maret 2018, Komnas HAM merilis ada 568 berkas pengaduan pelanggaran HAM. $^{6}$

Di samping itu, Komisi untuk Orang Hilang dan Korban Kekerasan (Kontras) menggarisbawahi beberapa masalah dalam perlindungan hak asasi manusia di Indonesia, seperti rekonsiliasi dan ambiguitas agenda keadilan; luka-luka/isu lama yang dihiduphidupkan kembali (seperti isu komunisme); jalan yang panjang dan berliku untuk Komisi Kebenaran dan Rekonsiliasi (KKR) Aceh; pencarian keadilan sosial untuk masyarakat di pulau-pulau terluar Indonesia; perampasan tanah oleh perusahaan semen di Rembang; proyek reklamasi di Bali, Romang dan Jakarta; pemilihan kepala daerah dan pemilih siluman (artificial voters); penggusuran dan pengabaian hak kolektif warga; pelanggaran hak penduduk asli dan keadilan sosial; penyiksaan oleh lembaga penegak hukum; Kasus pembunuhan Munir; Yusman dan politisasi hukuman mati; represi kebebasan berkeyakinan dan agama; ${ }^{7}$ represi kebebasan berserikat; ekspresi dan tantangan dalam perlindungan kelompok rentan; hukum dan terorisme; masa depan keadilan di Papua; masa depan gerakan hak asasi manusia, anti-korupsi dan lingkungan di Indonesia; dan reputasi HAM Indonesia yang ambigu dalam masyarakat Internasional, ${ }^{8}$ sebagaimana disoroti dalam Piagam Perserikatan Bangsa-Bangsa (The Charter of United Nations).

\footnotetext{
5 Data Rekap Pengaduan Komnas HAM Tahun 2016, diakses dari https://www.komnasham.go.id/files/20170117-data-pengaduan-tahun-2016-\$P5WKG.pdf

6 Lihat https://www.komnasham.go.id/index.php/data-pengaduan/

7 Rohidin, "Perspektif Hukum dan HAM terhadap Eksistensi Aliran Keagamaan di Indonesia", Pandecta Law Research Journal, Vol. 6 (1), 2011, hlm. 15-25.

8 Lebih jauh lihat Rezki Alvionitasari, 2017, "Kontras List Human Rights Violation in Indonesia", Berita Online, TEMPO, diakses dari https://en.tempo.co/read/news/2017/03/15/055856117/Kontras-Lists-HumanRights-Violations-in-Indonesia; HS Dillon, et.al., 2015, "Civil Society Declaration Demand The Real
} 
Piagam Perserikatan Bangsa-Bangsa sendiri, yang merupakan dasar konstitusional untuk semua instrument hukum hak asasi manusia Internasional, yang memadukan pandangan sejarah sebelum dan sesudah, dan yang akan datang (backward-progressive). Piagam ini menyatakan bahwa hak asasi manusia sebagai elemen tak terpisahkan untuk kelangsungan hidup umat manusia. Pemenuhan dan penghormatan HAM ditegaskan sebagai salah satu tujuan utamanya dan promosi penghormatan universal untuk, dan ketaatan, hak asasi manusia dan kebebasan fundamental untuk semua tanpa perbedaan seperti ras, bahasa, atau agama. ${ }^{9}$ Representasi hak asasi manusia ini menuntut kepastian moral dan sejarah dan keyakinan akan kebenaran-kebenaran fundamental tertentu. Deklarasi Universal Hak Asasi Manusia, menjadi dokumen penting dari semua dokumen hak asasi manusia, ${ }^{10}$ namun dokumen hak asasi manusia ini menimbulkan banyak pertanyaan dan masalah normatif dan budaya, terutama dalam konteks sejarah dan akar dari gerakan hak asasi manusia ${ }^{11}$, yang berakar pada pandangan dua konsep HAM — universalisme dan relativisme.

Dokumen-dokumen lain-yang berbicara tentang standar hak asasi manusia — adalah ICCPR and ECOSOC, bahwa setiap orang bebas menentukan status politik mereka dan bebas memilih perkembangan ekonomi, sosial dan budaya mereka. Namun, sebagaimana dijelaskan sebelumnya - masalah standar hak asasi manusia global dalam implementasi nasionaltulisan ini mencoba melihat pemenuhan standar hak asasi manusia di Indonesia dalam berbagai aspek. Persepsi standar akan menjadi fokus masalah pada tulisan ini. Seperti disoroti sebelumnya oleh Kontras, bahwa ada banyak kasus mengenai pelanggaran hak asasi manusia yang dipicu oleh interpretasi yang tidak sama pada standar terutama dalam konteks penegakan hukum itu sendiri.

Konsep hak asasi manusia, menurut Michael Freeman ${ }^{12}$, dapat menimbulkan kesulitan lebih lanjut karena konsep tersebut merentang jauh melampaui kasus-kasus kekejaman dan ketidakadilan ekstrem yang pernah terjadi, misalnya dalam kasus pelanggaran HAM berat,

Justice For Victims of Human Rights Violations in Indonesia”, Online Press Release, Kontras, diakses dari http://www.kontras.org/eng/index.php?hal=siaran_pers\&id=279

$9 \quad$ The UN Charter Pasal 55 (c)

10 UDHR berpendapat dalam pembukaannya bahwa "mengabaikan dan menghina hak asasi manusia telah menghasilkan tindakan barbar" dan bahwa martabat manusia, kebebasan, dan perdamaian hanya dapat dicapai jika hak asasi manusia dihormati. Lihat Deklarasi Universal Hak Asasi Manusia (UDHR)

11 Mary Ann Glendon, 1998, "Knowing the Universal Declaration of Human Rights", Notre Dame Law Review Vol. 73 No. 5, 1998, hlm. 11-53; Makau Mutua, 2002, Human Rights: A Political Cultural Critique, USA: University Pennsylvania Press, hlm.15; Philip Alston, 1988, "Making Space for New Human Rights: The Case of the Right to Development", Harvard Human Rights Year Books Vol. 3 No. 3, hlm. 345-346; Thomas M. Franck, 1992, "The Emerging Right to Democratic Governance", Amsterdam Journal of International Law, Vol. 86 No. 6, hlm. 46.

12 Michael Freeman, 2017, Key Concepts of Human Rights, Polity Press, Cambridge UK, hlm 25-27. 
kebebasan terhadap agama dan keyakinan, dan kasus-kasus lainnya di banyak negara. Maka, tulisan ini mengkaji tiga hal penting sebagai berikut, yakni:

1. Bagaimana analisis atas penegakan hukum dan pemenuhan hak asasi manusia berdasarkan konsep universalisme dan relativisme HAM di Indonesia?

2. Bagaimana perbedaan interpretasi HAM berkaitan dengan hak-hak sipil, politik, ekonomi, sosial dan budaya yang terjadi di Indonesia?

3. Bagaimana tantangan penegakan dan pemenuhan hak asasi manusia di Indonesia?

\section{B. PEMBAHASAN}

1. Penegakan Hukum dan Pemenuhan Hak Asasi Manusia di Indonesia Berdasarkan Konsep Universalisme dan Relativisme Hak Asasi Manusia

Amandemen Keempat UUD Negara Republik Indonesia 1945, bahwa cakupan perlindungan hak asasi manusia diperluas. Pasal 28 dari Konstitusi yang diamendemen hanya ditujukan untuk prinsip-prinsip hak asasi manusia. Pasal ini menjamin hak asasi manusia yang diterima secara universal, yaitu hak atas kebebasan berkumpul, hak untuk hidup, hak untuk membentuk keluarga, hak untuk pengembangan pribadi, hak untuk diperlakukan, sama di hadapan hukum, hak untuk bekerja dan pekerjaan, hak beragama dan kebebasan untuk menyatakan pendapat, hak atas informasi, kebebasan dari penyiksaan dan perlakuan tidak manusiawi dan merendahkan martabat, hak atas lingkungan yang sehat, dan hak untuk bebas dari perlakuan diskriminatif. ${ }^{13}$ Kesetaraan di hadapan hukum, perlindungan terhadap kebebasan beragama, dan hak atas pendidikan tetap dalam aturan yang sama pada Pasal 27, Pasal 29, dan Pasal 31, secara berturut-turut.

Salah satu perkembangan terpenting dalam pengarusutamaan hak asasi manusia di Indonesia adalah pembentukan aturan hukum HAM nasional. Pasal 1 ayat (1) UndangUndang No. 39 tahun 1999 tentang Hak Asasi Manusia (Undang-Undang HAM), mendefinisikan hak asasi manusia sebagai: “...seperangkat hak yang melekat pada hakikat dan keberadaan manusia sebagai makhluk Tuhan Yang Maha Esa dan merupakan anugerahNya yang wajib dihormati, dijunjung tinggi dan dilindungi oleh negara, hukum dan Pemerintah, dan setiap orang demi kehormatan serta perlindungan harkat dan martabat manusia."

\footnotetext{
${ }^{13}$ Lihat Amandemen Keempat UUD Negara Republik Indonesia 1945: Pasal 28, Pasal 28A, Pasal 28B, Pasal 28C, Pasal 28D (1), Pasal 28D (2), Pasal 28E, Pasal 28F, Pasal 28G (2), Pasal 28H (1), Pasal 28 I (1), dan Pasal $28 \mathrm{I}(2)$.
} 
Sehubungan dengan situasi hak asasi manusia di Indonesia, terutama dalam pengembangan sistem hukum hak asasi manusia, Hadiprayitno pernah menegaskan bahwa Hukum Hak Asasi Manusia mengadopsi prinsip persamaan dan non-diskriminasi, prinsip hakhak adat, tetapi tidak prinsip penentuan nasib sendiri. Hukum Hak Asasi Manusia melindungi hak kesetaraan, hak untuk hidup, hak atas keadilan, hak atas kebebasan individu sehubungan dengan perbudakan, hak agama, keyakinan politik, dan kebebasan berbicara. Berkenaan dengan hak ekonomi, sosial, dan budaya, berbagai hak yang diakui secara internasional juga dijamin oleh hukum ini di sini, seperti hak atas properti dan kepemilikan, hak untuk bekerja, dan hak atas pendidikan. ${ }^{14}$

Baik UUD 1945 dan Undang-Undang HAM, keduanya menegaskan gagasan tanggung jawab manusia disamping hak asasi manusia. Pasal 28(J) menggarisbawahi bahwa "dalam melaksanakan hak-haknya dan kebebasannya, setiap orang memiliki kewajiban untuk menerima pembatasan yang ditetapkan oleh hukum untuk tujuan menjamin pengakuan dan penghormatan hak-hak dan kebebasan orang lain dan berdasarkan pertimbangan moralitas, nilai-nilai agama, keamanan dan ketertiban umum dalam masyarakat demokratis". UndangUndang HAM, gagasan tanggung jawab manusia yang ditandai secara jelas pada Pasal 1 ayat (2), dimana bahwa memilih pemikul kewajiban dibandingkan mengharuskan setiap orang untuk bertanggung jawab, “...kewajiban dasar manusia adalah seperangkat kewajiban yang apabila tidak dilaksanakan, tidak memungkinkan terlaksananya dan tegaknya hak asasi manusia."

Pengakuan konsep tanggung jawab manusia menunjukkan pentingnya relativisme dalam perlindungan hak asasi manusia di Indonesia. Dalam praktiknya, Rencana Aksi Nasional Hak Asasi Manusia 1998-2003 menjelaskan hal ini sehubungan dengan promosi dan perlindungan hak asasi manusia harus diilhami oleh nilai-nilai, kebiasaan, budaya, dan tradisi Indonesia. Tentunya, pandangan ini menegaskan konsep relativisme dalam hak asasi manusia, dimana menurut Amartya Sen ${ }^{15}$, hak asasi manusia dianggap sebagai seperangkat tujuan dimana masing-masing masyarakat bisa mengembangkan tujuan tersebut, dan menurutnya, hak asasi manusia adalah artikulasi dari tuntutan-tuntutan etika yang bersifat terbuka. Pendapat Sen tersebut mendukung relativisme budaya karena tujuan yang ingin dicapai didalam hak asasi manusia harus memperhatikan nilai-nilai yang ada di masyarakat. Sebab-sebab yang mendasari pendapat Sen adalah bahwa masing-masing budaya, tradisi atau agama mempunyai

14 Irene Istiningsih Hadiprayitno, 2010, "Defensive Enforcement: Human Rights in Indonesia”, Human Rights Review, Vol. 11, hlm. 373-399.

15 Lihat selengkapnya pendapat Sen dan beberapa pendapat ahli hak asasi manusia lainnya di Schulz, S.H., 2008, "Limiting Sovereign Immunity in the Age of Human Rights", Harvard Human Rights Journal, Vol. 21 No. 1 , hlm.124. 
ciri khas tentang etika dan moralitas yang berbeda-beda. Itulah yang kemudian melahirkan nilai yang pluralis tentang hak asasi manusia. Masing-masing individu yang mempraktikan pluralisme nilai tersebut juga berbeda secara fisik, psikologis, atau mempunyai latar belakang ekonomi dan lingkungan yang berbeda.

Berbagai kasus yang ada berkaitan dengan pandangan ini-relativisme hak asasi manusia - misalnya berkaitan dengan kebebasan beragama dan berkeyakinan. Pada konteks universal, kebebasan ini tidak dibatasi oleh apapun atau dalam bahasa empat kebebasan (four freedoms), kebebasan ini ditegaskan bahwa setiap orang bebas meyakini Tuhan dengan caranya masing-masing (freedom of every person to worship God in his own way). Namun praktiknya berbeda di tiap negara, termasuk Indonesia. Indonesia menerapkan prinsip pembatasan agama yang diakui secara resmi, meskipun belakang Indonesia juga mengakomodir ajaran keyakinan sebagai salah satu identitas warga negara. Bahkan, Abdullahi Ahmed An Na'im ${ }^{16}$ juga mengatakan bahwa kesulitan utama untuk mengembangkan standar universal lintas budaya, dan khususnya agama adalah karena masing-masing tradisi tersebut berasal dari aturan dan norma-norma dari sumber mereka sendiri. Ketika ada pertentangan antara doktrin budaya dengan prinsip universalisme hak asasi manusia sebagai akibat dari persinggungan dua tradisi yang berbeda tersebut, maka bisa terjadi 'konflik hukum' yang bisa mengakibatkan penolakan dari salah satu tradisi tersebut. Ketika suatu negara berpegang teguh pada konsep relativisme budaya yang ada didalam masyarakatnya, maka praktik-praktik negara tersebut bisa sangat mudah melanggar hak kebebasan beragama yang bersifat universal. Selain perihal agama dan keyakinan, relativisme HAM juga banyak diterapkan dalam kondisi-kondisi lainnya, seperti kebebasan berbicara, berekspresi, berkumpul, hingga hak untuk hidup.

Relativisme inilah yang dalam banyak kasus, menimbulkan berbagai permasalahan baik dalam tingkat nasional maupun internasional. Misalnya, pemenuhan hak asasi manusia di Indonesia, jika mengacu pada banyak kasus dan menurut beberapa data dari banyak lembaga hak asasi manusia atau LSM, menempatkan negara ini pada peringkat yang rendah dari komitmen pemenuhan hak asasi manusia. Hal ini pernah ditegaskan oleh Freedom House pada Tahun 2016, bahwa indeks kebebasan Indonesia masih dalam angka yang rendah, di mana penegakan hukum merupakan komponen dengan pencapaian terendah. Di sisi lain, Reporters Without Borders pada 2016 menempatkan Indonesia pada 130/180 dengan indeks kebebasan pers di 41,72 menurun 0,97 persen dari 2015. Penilaian dari dua organisasi

16 An-Na'im, Abdullahi Ahmed, 1990, Toward an Islamic Reformation, Civil Liberties, Human Rights, and International Law, Syracuse University Press, New York, hlm. 162. 
internasional terhadap situasi kebebasan Indonesia pada kenyataannya tidak menunjukkan perubahan ke masa depan yang lebih baik selama dua tahun terakhir.

Terdapat sejumlah kasus intimidasi terhadap jurnalis, pembubaran diskusi, kriminalisasi terhadap ekspresi sah baik online maupun offline, masih terjadi. Situasinya bahkan lebih buruk di tengah-tengah Tahun 2016. ${ }^{17}$ Bahkan, Lembaga Studi dan Advokasi Masyakarat (ELSAM) pada Tahun 2016 menegaskan bahwa selama beberapa tahun, Pemerintah Indonesia belum menunjukkan dirinya sebagai gatekeeper dalam tanggung jawab perlindungan dan pemenuhan hak asasi manusia, terlepas dari berbagai catatan pemerintah yang berbeda dan juga diskusi nasional dan internasional.

Beberapa permasalahan hak asasi manusia di Indonesia, sebagaimana dirilis oleh eLSAM $^{18}$, yakni: Pertama, kegagalan pemerintah Indonesia untuk menjamin kenyamanan dan perlindungan berkaitan dengan hak kebebasan berekspresi, khususnya di dunia maya. Revisi UU No. 11 tahun 2008 tentang Informasi dan Transaksi Elektronik (UU ITE), berubah menjadi antisipasi untuk menjamin perlindungan terhadap kebebasan berbicara dan berekspresi, namun sebenarnya masih menawarkan peluang untuk pelanggaran hak asasi manusia. Selain memberikan legitimasi untuk tindakan kekerasan, revisi peraturan ini juga memberikan kewenangan yang luas bagi otoritas untuk memblokir konten bersih yang dianggap melanggar hukum. Tanpa adanya jaminan dan proses yang jelas, tindakan tersebut berpotensi menghambat hak orang untuk menikmati dan mendapatkan informasi, termasuk kebebasan menyampaikan pidato dan ide. ${ }^{19}$

Kedua, penangkapan sejumlah orang dengan tuduhan melakukan tindakan penyerangan menurut ELSAM juga menunjukkan kecerobohan aparat penegak hukum dalam menerapkan ketentuan tersebut. Sebagai contoh: penangkapan ratusan aktivis HAM untuk Papua yang melakukan demonstrasi damai pada 1 Desember 2016 untuk merayakan kemerdekaan Irian Barat, dan penangkapan beberapa orang yang diduga terlibat pada 2 Desember 2016. Penggunaan ketentuan ini tanpa kejelasan unsur-unsurnya pasti akan terjadi, dan menjadi berbahaya bagi kelangsungan sistem demokrasi konstitusional yang pada dasarnya menekankan pada kebebasan berbicara dan berekspresi.

17 Dodi Sanjaya, 2016, "Human Rights Are (Still) Under The Threats: Government Has Not Fulfilled Its Human Rights Commitment Promises", Press Release ELSAM, Jakarta, ELSAM, diakses dari http://elsam.or.id/2016/12/human-rights-are-still-under-the-threats-government-has-not-fulfilled-its-humanrights-commitment-promises/

18 Lihat Press Release eLSAM, Ibid.

19 Ibid. 
Ketiga, kasus intimidasi terhadap jurnalis yang terjadi pada tahun 2016, misalnya perampasan kamera dan hasil foto (Malang), pengusiran (Banceuy, Dogiyai), dan pelaporan pelarangan dan penganiayaan (Padang, Bulukumba, Lampung). Komitmen Pemerintah Indonesia pada Deklarasi Windhoek 1991 dipertanyakan, dengan mempertimbangkan bahwa intimidasi dan kekerasan terhadap jurnalis adalah bentuk-bentuk pengabaian independensi dan keragaman jurnalistik. Perlindungan terhadap jurnalis merupakan pondasi penting dalam demokrasi, yang dimaksudkan untuk meningkatkan akses ke sumber informasi, mendorong analisis informasi dan mempromosikan ekspresi beragam pendapat, terutama pada saat-saat krisis yang dikatakan oleh Frank La Rue. ${ }^{20}$

Keempat, penunjukan Jenderal Wiranto sebagai Menteri Koordinator Bidang Politik, Hukum, dan Keamanan merupakan kemunduran besar pada tahun 2016. Pada tahun 2003, Wiranto didakwa oleh Unit Kejahatan Berat PBB (UN Serious Crimes Unit) untuk bertanggung jawab atas pembantaian dan serangkaian penganiayaan di Timor Leste. Komisi Nasional Hak Asasi Manusia (Komnas HAM), dalam laporannya, menyebutkan bahwa Wiranto juga harus bertanggung jawab atas Penembakan Trisakti, Kerusuhan Mei 1998, juga Kerusuhan Semanggi 1 dan Semanggi 2. Pengangkatan Wiranto merupakan kekecewaan besar bagi masyarakat sipil karena posisinya di pemerintahan akan menghambat proses dalam menyelesaikan pelanggaran hak asasi manusia di masa lalu, di mana Wiranto sendiri diduga terlibat dalam pelanggaran. Keputusan pemerintah dapat diartikan sebagai bentuk pengabadian impunitas dan memberikan contoh buruk bagi semua upaya dalam menciptakan perdamaian, juga untuk penegakan hukum. ${ }^{21}$

20 Frank La Rue menjelaskan bahwa salah satu tantangan terbesar untuk memastikan perlindungan jurnalis adalah impunitas atau kegagalan untuk mengadili para pelaku pelanggaran hak asasi manusia. Dalam hal ini, Pelapor Khusus (the Special Rapporteur) dalam banyak kesempatan menekankan bahwa impunitas bagi mereka yang menyerang dan / atau membunuh jurnalis adalah hambatan utama untuk menjamin perlindungan jurnalis dan kebebasan pers, karena itu memberi semangat dan peluang bagi para pelaku dan juga calon pelaku untuk menyerang wartawan tanpa konsekuensi hukum. Impunitas menjadi salah satu penyebab utama banyaknya jurnalis yang diserang atau dibunuh setiap tahun. Negara harus mengakui bahwa dalam kasus-kasus kekerasan terhadap jurnalis, impunitas menghasilkan lebih banyak kekerasan dalam lingkaran setan. Lihat Frank La Rue, 2012, "Report of the Special Rapporteur on the Promotion and Protection of the Right to Freedom of Opinion and Expression", Human Rights Report $21^{\text {th }}$ Session, Human Rights Council the United Nations General Assembly, hlm. 11-12., diakses dari http://www.ohchr.org/Documents/HRBodies/HRCouncil/RegularSession/Session20/A-HRC-20-17_en.pdf

21 Setara Institute menyatakan bahwa pemerintah tidak memiliki komitmen penuh untuk menyelesaikan pelanggaran hak asasi manusia di masa lalu, serta wacana penyelesaian pelanggaran hak asasi manusia hanya menjadi manuver politik pemerintah. Lihat lebih lanjut Kristian Erdianto, 2017, "Realisasi Penegakan HAM Era Jokowi, Lain Dulu Lain Kini”, KOMPAS Online, diambil dari https://nasional.kompas.com/read/2017/02/21/11113781/realisasi.penegakan.ham.era.jokowi.lain.dulu.lain.k ini 
Kelima, pemerintah Indonesia juga masih menerapkan praktik hukuman mati. Ada 4 orang yang dijatuhi hukuman mati karena kasus narkotika, yang pelaksanaannya telah dilakukan pada 29 Juli 2016. Namun, mereka akhirnya dieksekusi meskipun tiga dari mereka masih belum mendapat tanggapan atas pengajuannya. Pada tanggal yang sama, otoritas menunda eksekusi mati sepuluh terpidana mati pada menit terakhir sehingga pemerintah dapat memeriksa kembali kasus mereka, setelah diberi tekanan dari komunitas nasional dan internasional. Selain ketidakmanusiawiannya, praktik ini juga tidak sejalan dengan kerapuhan sistem peradilan pidana Indonesia, di mana peluang kesalahan dugaan sangat tinggi. Dalam beberapa kasus, keyakinan yang salah sering tak terelakkan dalam praktik sistem peradilan pidana. $^{22}$

\section{Interpretasi atas Pemenuhan Hak-Hak Sipil, Politik, Ekonomi, Sosial dan Budaya dalam Konteks Universalime dan Relativisme Hak Asasi Manusia di Indonesia}

Universal of Declaration of Human Rights (UDHR) menggarisbawahi bahwa “... adalah penting, jika manusia tidak dipaksa untuk mencari jalan keluar, sebagai jalan terakhir, untuk memberontak melawan tirani dan penindasan, bahwa hak asasi manusia harus dilindungi oleh aturan hukum." ${ }^{, 3}$ Pernyataan itu berarti bahwa, untuk memenuhi hakhak orang, mereka harus dilindungi secara efektif oleh sistem hukum nasional. Dengan demikian, prinsip rule of law dapat digambarkan sebagai prinsip yang menyeluruh di bidang perlindungan hak asasi manusia karena, jika tidak ada, penghormatan terhadap hak asasi manusia menjadi ilusi. ${ }^{24}$

Sebagai masalah selanjutnya, perkembangan hak asasi manusia dalam konteks penegakan hukum serta pemenuhan hak asasi manusia itu sendiri, menghadapi banyak kendala, termasuk juga di Indonesia. Indonesia sebagai negara berdasarkan hukum yang salah satu unsur yang ditentukan dalam prinsip negara hukum sebagaimana dijelaskan oleh Stahl adalah pemenuhan hak dasar atau hak dasar dalam bentuk perlindungan Hak Asasi Manusia. Sedangkan instrumen utama dalam mewujudkan pemenuhan hak-hak dasar warga adalah Kekuasaan Kehakiman dan badan-badan lain yang merupakan kekuatan independen untuk menyelenggarakan peradilan untuk menegakkan hukum dan keadilan sebagaimana dinyatakan dalam Pasal 24 UUD 1945. Meskipun Indonesia memiliki beberapa dasar hukum perlindungan hak asasi manusia seperti Undang-Undang Hak Asasi Manusia dan UUD 1945, interpretasi dalam mendefinisikan hak asasi manusia masih menjadi masalah penting dalam pelaksanaan perlindungan dan pemenuhan hak asasi manusia.

22 Dodi Sanjaya, 2016, Op.Cit.

23 Pada bagian pembukaan (preambule) paragraf ketiga ditegaskan: "Whereas it is essential, if man is not to be compelled to have recourse, as a last resort, to rebellion against tyranny and oppression, that human rights should be protected by the rule of law." Lihat United Nations, Universal Declaration of Human Rights, diakses pada http://www.un.org/en/universal-declaration-human-rights/

24 Ridwan Arifin, 2017, "Revealing the Other Side of Human Rights Issue: How We Look to the Existed Various Problems”, Journal of Indonesian Legal Studies, Volume 2 (1), hlm. 79-82. 


\section{a. Interpretasi Hak Sipil dan Politik (Civil and Political Rights)}

Kebebasan berbicara dan kebebasan berkumpul adalah dua hal yang mendominasi dalam permasalahan berkaitan dengan hak sipil dan politik di Indonesia. Hak-hak ini telah disebutkan sebagai bagian yang sangat penting sejak kemerdekaan Indonesia. Bahkan versi sebelumnya dari Pasal 28 UUD 1945 menjamin kebebasan berbicara dan kebebasan berkumpul. Namun, di bawah era Suharto, kedua hak itu secara sistematis telah dikekang. Pemerintah memberlakukan pedoman dan aturan hukum tambahan yang membatasi kebebasan berbicara baik untuk individu maupun media. Kenyataannya, pemerintah menggunakan peraturan yang digunakan untuk menjerat penjahat dan hukum yang melarang subversi terhadap mereka yang menjalankan kebebasan berbicara bertentangan dengan pihak berwenang. $^{25}$

Setelah mundurnya Suharto, kebebasan berbicara mendapatkan jaminan yang lebih jelas. Pers dan Publikasi Masyarakat Indonesia atau MPPI (Masyarakat Pers dan Penyiaran Indonesia) menjadi mampu memprovokasi rancangan peraturan tentang Kebebasan Pers di DPR. Pada 23 September 1999, Habibie dan DPR mengadopsi undang-undang No. 40 tahun 1999, yang menjamin kebebasan pers dari campur tangan pihak berwenang. Karena itu, semakin banyak surat kabar, majalah, radio, dan stasiun televisi dan mereka dapat mendokumentasikan hampir sesuatu yang tidak memiliki sensor pemerintah. Namun, perkembangan dalam kebebasan berbicara selama manajemen Habibie tidak hanya sebagai hasil akhir dari peraturan ini. Sebaliknya, hal tersebut menjadi satu perkembangan dari kebebasan setiap orang yang diterjemahkan dalam pikiran bebas tanpa batas yang menyebabkan orang tidak lagi takut menyuarakan keprihatinan mereka. Masyarakat umum mungkin ingin mengungkapkan secara bebas semua masalah yang ada, tanpa kecemasan, seperti masalah yang sensitive, oleh karena itu, kebebasan berbicara menjadi tidak hanya ditujukan pada liberalisasi pers, tetapi juga mengkritik dan membuka pandangan politik bagi semua orang untuk secara terbuka mengkritik kebijakan dan tindakan pemerintah, sesuatu yang berubah dari permintaan sebelumnya. ${ }^{26}$

Saat ini, wacana kebebasan berbicara di Indonesia telah didominasi oleh masalahmasalah berkaitan dengan pornografi dan kecabulan/asusila di tempat-tempat umum. Meningkatnya jumlah dan jenis media telah mendorong peningkatan jumlah unggahan snapshot dan foto album kenangan semi-pornografi. Gerakan Muslim berhasil mendorong DPR untuk merespon hal tersebut dengan cara menyusun peraturan anti-pornografi. Rancangan peraturan ini mendefinisikan tindakan-tindakan pornografi sebagai kegiatan yang dengan sengaja mengungkapkan dan/atau menjadikan aktivitas yang paling seksual, tidak senonoh, dan/atau erotis (Juwana, 2006: 374).

25 Hikmahanto Juwana, 2006, 'Human Rights in Indonesia'. In Randall Peerenboom et.al. (eds), Human Rights in Asia: A Comparative Legal Study of 12 Asians Jurisdictions, France, and the USA, New York: Routledge, hlm. 364-383, Lihat juga Irene Istiningsih Hadiprayitno, 2010, Op.cit.

26 Irene Istiningsih Hadiprayitno, 2010, Op.Cit. 
Pada tanggal 9 Desember 2009, setelah persetujuan dari Presiden Yudhoyono aturan tersebut telah diberlakukan dan telah menjadi Undang-Undang Nomor 44 tahun 2008 tentang Pornografi. Undang-undang tersebut dianggap memicu banyak tindakan kekerasan dan kriminalisasi dalam berbagai kasus.

Semakin berkembangnya isu pornografi, yang terjadi semakin memicu meningkatnya penggunaan hukum Syariah melalui berbagai peraturan daerah. Maka penerapan UndangUndang Nomor 32 tahun 2004 tentang Pemerintahan Daerah, sebagaimana diperbaharui dengan Undang-Undang No. 23 Tahun 2014, memberikan peluang bagi pemerintah daerah untuk menerapkan pedoman hukum yang relevan dengan keinginan daerahnya. Sehingga, pada beberapa daerah, hal ini diterjemahkan sebagai implementasi dari peraturan Syariah dalam kehidupan sehari-hari. Hingga saat ini, peraturan ini secara tidak proporsional, sebagai salah satu contoh penerapan aturan tersebut mempengaruhi para wanita. Di daerah Tangerang, setidaknya 11 gadis telah ditangkap hanya karena mereka keluar beraktivitas di malam hari dengan riasan. Di Aceh, tiga aktivis perempuan telah ditangkap oleh polisi Syari'ah karena tidak mengenakan kerudung dan berbicara di depan kamar penginapan mereka setelah mengikuti pelatihan hak asasi manusia. ${ }^{27}$

Lebih jauh, dengan mengakui kebebasan berkumpul, Undang-Undang No. 9 Tahun 1998 tentang Kemerdekaan Menyampaikan Pendapat di Muka Umum, mengatur waktu, wilayah, dan prosedur untuk mengadakan demonstrasi di lokasi publik. Meskipun peraturan tersebut memberikan konsekuensi mulai dari penyebaran pertemuan sampai hukuman penjara bagi orang yang bertanggung jawab atas pertemuan, pembatasan metode pertemuan termasuk seminar, diskusi kelompok, dan seminar akademik telah sangat fleksibel. Izin tidak lagi diperlukan untuk kegiatan tersebut, hanya penyelenggara wajib memberi tahu polisi tentang kegiatan tersebut. ${ }^{28}$ Sayangnya, menurut Hadiprayitno bahwa protes dan demonstrasi secara teratur menyebabkan tindakan kekerasan dan merugikan. Demonstrasi seringkali menyebabkan antipati dan ketidak-nyamanan publik. Demonstrasi menyebabkan gangguan dalam infrastruktur publik, bersama dengan memblokir jalan raya dan menimbulkan masalah lalu lintas. ${ }^{29}$

Guna menegaskan perlindungan yang sama dalam hak-hak sipil dan politik, penegakan hukum menjadi bagian yang sangat penting, dimana negara seharusnya hadir dalam menciptkan kondisi yang memungkinkan setiap orang berbicara dan kebebasan berkumpul, serta menyaampaikan pendapat—bahkan perbedaan pendapat.

Ibid., hlm. 380 .

Ibid., hlm. 381.

Ibid. 


\section{b. Interpretasi Hak Ekonomi, Sosial dan Budaya (Economic, Social, and Cultural Rights)}

Hampir serupa dengan sebelumnya (Hak Sipil dan Politik), Hak ekonomi, sosial, dan budaya mendapat perhatian lebih setelah pengunduran diri Suharto. Selain ratifikasi Kovenan Internasional Hak Ekonomi, Sipil, dan Politik, popularitas hak ini juga dapat diamati dalam inisiatif yang berkembang yang diambil untuk mempromosikan serangkaian hak ini oleh organisasi masyarakat sipil. Kondisi ini berbeda jika dibandingkan dengan aktivitas hak asasi manusia pra-1998, yang kebanyakan terkonsentrasi pada domain hak sipil dan politik, karena rangkaian hak ini dianggap yang paling dilanggar. Setelah krisis, masalah ekonomi, sosial, dan budaya lebih nyata dan mendesak dan oleh karena itu mendapat perhatian lebih.

Alasan lainnya adalah kesadaran hak-hak ekonomi, sosial, dan budaya muncul akibat dari dampak krisis ekonomi terhadap kondisi ekonomi dan sosial di Indonesia. Indeks kemiskinan manusia (Human Poverty Index, HPI), yang dikembangkan oleh Program Pembangunan Perserikatan Bangsa-Bangsa (1997), berupaya untuk menyediakan ukuran kemampuan secara agregat dengan menggabungkan empat indikator, yaitu harapan hidup, tingkat melek huruf orang dewasa, akses ke air minum yang lebih baik, dan proporsi berat badan kurang anak-anak di bawah usia lima tahun. Perkiraan HPI untuk Indonesia adalah sekitar $34,7 \%$ sebelum krisis tetapi turun ke $23,2 \%$ pada tahun $2000^{30}$. Menurunnya kualitas hidup memicu organisasi masyarakat sipil untuk bereaksi ketika pelanggaran mudah diamati dan dipantau. Mereka menganggap terutama masalah kelaparan, perlindungan pekerjaan yang buruk, dan kerentanan orang yang paling kurang beruntung terhadap risiko kesehatan sebagai masalah yang paling penting dalam hal hak ekonomi, sosial, dan budaya di Indonesia. ${ }^{31}$

Salah satu tantangan tersendiri dalam mempromosikan hak ekonomi, sosial, dan budaya di Indonesia adalah pada isu pengarusutamaan perspektif hak asasi manusia dalam hukum dan kebijakan ekonomi, sosial, dan budaya. Undang-Undang Kesehatan No. 23 Tahun 1992, misalnya, hanya memberikan panduan umum untuk ketersediaan layanan kesehatan di Indonesia, tanpa memandang kesehatan sebagai bagian dari martabat manusia. Selanjutnya, sebagai hak asasi manusia, perawatan kesehatan juga harus bisa diklaim di tingkat hukum. Ketiadaan hak penting ini ditemukan dalam undang-undang lain yang terkait dengan hak ekonomi, sosial, dan budaya seperti Undang-Undang Sistem Pendidikan No. 2 Tahun 1989 atau Undang-Undang Ketahanan Pangan No. 7 Tahun 1996. Khususnya diadopsi oleh rezim Orde Baru, undang-undang ini tidak lagi relevan untuk perlindungan hak atas kesehatan, hak atas pendidikan, dan hak atas pangan yang ditetapkan oleh Undang-undang Hak Asasi

30 Shafiq Dhanhani, Iyanatul Islam, 2002, "Poverty, Vulnerability, and Social Protection in Period of Crisis", World Development, Vol. 30, No. 7, hlm 1213-1214; I Made Budi Arsika, Ni Gusti Ayu Dyah Satyawati, Sagung Putri M.E. Purwani, 2016, "Isu Hak Asasi Manusia dalam Penerapan Deportasi terhadap Tenaga Kerja Asing di Bali”, Pandecta Law Research Journal, Vol. 11 No.1, hlm. 1-17.

31 Ibid. 
Manusia No. 39 Tahun 1999. Namun demikian, sejauh ini belum ada diskusi tentang merevisi undang-undang tersebut.

Undang-undang yang diadopsi setelah Orde Baru juga jauh dari sempurna, karena masih rentan terhadap tantangan yang datang dari aktor-aktor berpengaruh. Undang-undang tentang Angkatan Kerja No. 13 Tahun 2003 adalah sebuah contoh. Ketentuan undang-undang yang benar-benar menguntungkan pekerja sedang diperebutkan oleh Asosiasi Pengusaha Indonesia (Apindo). Organisasi saat ini menuntut revisi untuk menghapus beberapa ketentuan yang menguntungkan terkait dengan standar gaji, fasilitas kesejahteraan, perhitungan kompensasi, dan kemungkinan bagi pekerja untuk melakukan protes dan demonstrasi. Secara khusus, Apindo mengusulkan pengalihan kewajiban perlindungan pekerja dalam hal kesejahteraan, keselamatan, dan perawatan kesehatan kepada perusahaan daripada Negara sebagaimana telah diatur dalam UU No. 13 Tahun 2003 tentang Ketenagakerjaan. ${ }^{32}$ Jika kewajiban ini ditanggung oleh perusahaan, perusahaan juga akan memutuskan standar. Secara alami, ini dapat berdampak negatif terhadap posisi hak pekerja karena, sebagai entitas komersial, perusahaan lebih peduli dengan keuntungan daripada dengan kondisi pekerja. ${ }^{33}$

Tanggapan umum biasanya diajukan oleh pemerintah ketika dihadapkan dengan subjek hak ekonomi, sosial, dan budaya di Indonesia. Yang pertama terkait dengan masalah sumber daya. Meskipun fakta telah membuktikan bahwa negara ekonomi yang kuat tidak secara otomatis memberikan perlindungan yang baik terhadap hak-hak ekonomi, sosial, dan budaya, dianggap bahwa mempromosikan hak-hak ekonomi, sosial, dan budaya memerlukan alokasi sumber daya. Seperangkat hak ini terutama tergantung pada kemampuan dan diklaim terkait erat dengan situasi ekonomi negara yang bersangkutan. Sehubungan dengan Indonesia, alasan ini telah diulang oleh pemerintah dalam upaya untuk menebus kegagalan mereka untuk melaksanakan kewajiban mereka dalam mempromosikan dan melindungi hak-hak ekonomi, sosial, dan budaya. Bahkan, sering digunakan untuk menghindari kewajibannya. Kurangnya sumber daya dianggap rasionalisasi karena tidak terpenuhinya hak asasi manusia.

Dalam hal ini, pemerintah Indonesia bergantung pada aktivitas Internasional, yang berarti bantuan Internasional, untuk secara global memberantas kemiskinan yang melanggar pemenuhan hak-hak ekonomi, sosial, dan budaya. Pandangan seperti itu tercermin dalam pernyataan delegasi Indonesia sebelum The Fourth Session of the Permanent Forum on Indigenous Issues on agenda item "Eradicate Extreme Poverty and Hunger", yang menyatakan bahwa: negara-negara miskin harus dapat mengharapkan dukungan internasional yang dapat diandalkan sebagai sarana untuk menciptakan lapangan kerja dan mewujudkan pertumbuhan ekonomi secara umum, sebagai tanggapan terhadap tantangan kemiskinan. ${ }^{34}$

Pasal 35 (3), Undang-Undang No. 13 Tahun 2003 tentang Ketenagakerjaan

Ibid.

34 Lihat Economic and Social Council United Nations, 2005, "Permanent Forum on Indegenous Issues, Report on Fourth Sessions”, 16 27- Mei 2015, Laporan, Economic and Social Council UN, New York, hlm 1-39 
Namun, perlindungan - dalam konteks pemenuhan - hak-hak ekonomi, sosial, dan budaya bukan hanya tentang sumber daya. Ini hanya bagian dari tugas untuk memenuhi Negara Pihak yang terkait dengan serangkaian hak ini. Kewajiban untuk melindungi terutama tergantung pada kebijakan yang diadopsi yang menguntungkan yang benar-benar bertujuan untuk melindungi hak-hak ekonomi, sosial, dan budaya, sementara kewajiban untuk menghormati mengharuskan Pemerintah Indonesia untuk menahan diri dari mengadopsi undang-undang yang merampas hak para pemegang hak untuk mengakses hak-hak mereka. Ketidakmampuan dari undang-undang yang dijelaskan sebelumnya menunjukkan bahwa upaya untuk memenuhi dua kewajiban terakhir masih kurang. ${ }^{35}$

Selain itu, organisasi internasional, tempat di mana sumber daya diduga diduga, tidak dapat diharapkan untuk mengubah kebijakan nasional. Bahkan, hak-hak ekonomi, sosial, dan budaya bergantung pada identifikasi tidak terpenuhinya hak-hak asasi manusia yang dibuat oleh pelaku domestik, terutama organisasi non-pemerintah, media, dan pemegang hak. Selanjutnya, pengambilan keputusan kebijakan harus melibatkan orang-orang yang memiliki kedudukan yang paling jelas untuk menuntut alokasi tertentu dan yang biasanya adalah penduduk negara yang bersangkutan. Kelompok-kelompok ini pada saat yang sama dapat bertindak sebagai kelompok penekan untuk mencari klaim dan pemulihan dari pelanggaran hak-hak ekonomi, sosial, dan budaya. ${ }^{36}$

Hadiprayitno menekankan bahwa kurangnya perlindungan terhadap hak-hak orang pada hak-hak ekonomi, sosial, dan budaya memperburuk karena UU Pengadilan Hak Asasi Manusia No. 26 Tahun 2000 tidak memiliki yurisdiksi atas hak-hak ekonomi, sosial, dan budaya. Oleh karena itu, meskipun Undang-Undang Dasar 1945 dan Hak Asasi Manusia Nomor 39 Tahun 1999 Undang-Undang HAM (UU HAM), menjamin perlindungan terhadap hak asasi manusia, penegakan hak-hak ini praktis bermasalah. Undang-undang memang berfungsi sebagai pengungkap pelanggaran, tetapi tanpa kemungkinan klaim dan kompensasi, pemerintah Indonesia dapat terus berkonsentrasi pada jumlah pemenuhan generik, yang diukur dengan angka. Akibatnya, menjadi sulit bagi lembaga-lembaga hak asasi manusia, pejabat, atau organisasi masyarakat sipil untuk ikut campur ketika ada praktik-praktik tertentu yang salah, misalnya, penggusuran rumah yang tidak adil atau masalah kelaparan.

35 M. Sepulveda, 2003, The Nature of the Obligations under the International Covenant on Economic, Social and Cultural Rights, School of Human Rights Research Series, Utrecht University, Antwerp: Intersentia, hlm. 176-177; Irene Istiningsih Hadiprayitno, 2010, Op.Cit. hlm. 387

36 Roth mengatakan bahwa beberapa standar internasional telah dirumuskan oleh banyak badan internasional dan secara praktis, semua itu kadang-kadang berbeda dengan sistem hukum nasional atau bahkan kebijakan nasional dalam melindungi hak asasi manusia. Lihat Roth, Kenneth, 2004, "Defending Economic, Social, and Cultural Rights: Practical Issues Faced by International Human Rights Organisations", Human Rights Quarterly 26: 63-73; Irene Istiningsih Hadiprayitno, 2010, Ibid. 


\section{Permasalahan dalam Tantangan Pemenuhan Perlindungan Hak Asasi Manusia pada Konteks Penegakan Hukum di Indonesia}

Isu hak asasi manusia menjadi isu yang penting dalam kehidupan masyarakat dalam suatu Negara baik dari perspektif pemerintah maupun individu. Dari berbagai pengalaman dan kasus yang ada, penekanan pada pembicaran tentang hak asasi manusia sering mengarah pada generalisasi dan kesalahpahaman.

Berikut yang dapat kita lihat contoh sederhana bila seseorang diminta menyebutkan pentingnya hak asasi manusia kepada seseorang dan kita mungkin akan mendapatkan sejumlah tanggapan yang berbeda-beda, seperti beberapa kemungkinan reaksi terkait pendapat tentang konteks Hak Asasi Manusia yang bisa dijadikan pijakan ada kengganan untuk bicara langsung, missal kalimat dibawah ini:

"Tentu saja, semua orang membutuhkan hak asasi manusia; Saya sadar untuk hak asasi manusia, tetapi ini adalah perang; kita harus fleksibel dalam memerangi teroris yang tentunya tidak menghormati hak asasi manusia; Hak asasi manusia itu penting, tetapi bisakah kita benar-benar menjamin hak asasi manusia jika orang lain tidak menghormatinya? Hak asasi manusia memiliki sedikit makna, karena hak asasi manusia bagi sebagian orang mungkin berarti penindasan kepada orang lain”.

Kondisi ini menunjukkan kepada kita bahwa interpretasi hak asasi manusia serta konsep dan pemahaman masih memiliki banyak perbedaan. Laporan PBB pada 2006 menyoroti beberapa tantangan hak asasi manusia seperti: kemiskinan dan ketidakadilan global; diskriminasi; konflik bersenjata dan kekerasan; kekebalan hukum; defisit demokrasi; dan institusi yang lemah. Sementara itu, tantangan dalam implementasi perlindungan hak asasi manusia seperti: kesenjangan pengetahuan; kesenjangan kapasitas; kesenjangan komitmen; dan celah keamanan. ${ }^{37}$

Ada juga penggunaan bahasa yang sering menjadi masalah dalam keterkaitan interpretasi tentang pengertian HAM itu, beberapa penelitian sebelumnya dan temuan pakar menekankan kebingungan dan penyalahgunaan bahasa yang lazim dalam wacana tentang hak asasi manusia: penggunaan yang tidak dibedakan, terutama ekspresi seperti hak asasi manusia, hak fundamental, kebebasan sipil, dan lain-lain. Dua tren utama bersaing untuk menjelaskan perbedaan antara hak dasar dan hak lainnya. Para pendukung doktrin pertama mengklaim bahwa hak-hak dasar adalah hak prerogatif yang melekat pada pribadi manusia, yang berasal entah dari hak alami yang melampaui pengakuan mereka oleh Negara (termasuk kehidupan, martabat, kebebasan, kesetaraan, keamanan, dan properti). Sebaliknya, para pendukung gerakan positivis memandang bahwa hak-hak fundamental ini hanya dapat dijelaskan jika mereka diakui /diberikan oleh Negara. ${ }^{38}$

37 Lihat http://www.humanrights.com/voices-for-human-rights/human-rights-challenges.html

38 Lihat Forum Mondial des Droits de l'Homme, "Human Rights: Emerging Issues and Challenges", diakses dari http://fmdh-2014.org/en/les-droits-de-lhomme-nouvelles-questions-et-defis/ 
Bagi Indonesia sendiri, meskipun telah ada dokumen hak asasi manusia untuk memastikan pelaksanaan hak asasi manusia, dalam sejarahnya masih ada pelanggaran hak asasi manusia. Pelanggaran HAM di Indonesia terjadi karena meningkatnya gejala individualistik, materialistis, dan eksklusif. Pelanggaran ini dapat diatasi atau dimitigasi jika ada penegakan hak asasi manusia. Bangsa Indonesia juga telah mencoba melakukan upaya untuk menegakkan hak asasi manusia, tetapi banyak hambatan dan tantangan dalam penegakan hak asasi manusia.

Hambatan utama dalam penegakan HAM di Indonesia adalah masalah ketertiban dan keamanan nasional, rendahnya tingkat kesadaran hak asasi manusia, dan kurangnya instrumen hukum dan peraturan. Namun, secara umum hambatan ini dikelompokkan menjadi tiga macam, yaitu ideologis, ekonomi, dan teknis.

Secara ideologis, perbedaan ideologi sosialis dengan kaum liberalis membuat perbedaan tajam dalam pandangan hak asasi manusia. Pandangan ideologi liberal mengutamakan penghormatan terhadap hak pribadi, sipil, dan politik. Pandangan sosialis memprioritaskan peran negara dan masyarakat. Secara ekonomi, penegakan hak asasi manusia berkaitan dengan kondisi ekonomi masyarakat, dan semakin tinggi komunitas ekonomi maka seharusnya semakin tinggi upaya penegakan HAM. Secara teknis, penegakan hak asasi manusia secara teknis dibatasi karena belum meratifikasi instrumen hak asasi manusia internasional.

Dengan banyaknya hambatan untuk penegakan HAM, rakyat Indonesia berjuang untuk melakukan proses penegakan HAM. Proses penegakan HAM di Indonesia dilakukan dengan beberapa langkah dan upaya dengan harapan menjunjung tinggi hak asasi manusia di Indonesia. Pada dasarnya, gagasan tentang hak asasi manusia adalah keyakinan bahwa manusia dilahirkan ke dunia dalam anugerah ciptaan Tuhan setara dan setara dengan hak-hak mereka yang setara.

Di samping itu, meningkatnya jumlah kasus pelanggaran hak asasi manusia yang terjadi adalah tantangan penegakan HAM di Indonesia. Beberapa kasus pelanggaran hak asasi manusia telah diselesaikan, sementara yang lain masih sedang diupayakan. Meskipun banyak kasus pelanggaran hak asasi manusia di Indonesia, itu tidak berarti bahwa masalah penegakan hak asasi manusia dikatakan lemah atau tidak ada penegakan hukum. Namun, masih banyak masalah yang menjadi tantangan dalam implementasi penegakan HAM di negara ini.

Tantangan penegakan HAM di Indonesia termasuk: rendahnya tingkat kepercayaan publik terhadap pejabat pemerintah dan lembaga penegak hukum; masih ada pihak-pihak yang berusaha menghidupkan kembali kekerasan sistematis dan diskriminasi terhadap perempuan atau kelompok minoritas orang; budaya kekerasan seringkali masih menjadi pilihan berbagai kelompok masyarakat dalam menyelesaikan masalah yang ada di antara mereka; tidak adanya komitmen pemerintah yang kuat terhadap upaya penegakan hak asasi manusia dan kemampuan untuk menerapkan kebijakan HAM secara efektif sebagaimana diamanatkan oleh konstitusi; industri media massa yang mengakibatkan meningkatnya 
keterlibatan media massa dalam pemuatan laporan investigasi tentang hak asasi manusia dan pembentukan opini untuk mempromosikan hak asasi manusia; masih lemahnya kekuatan masyarakat (civil society) yang mampu menekan pemerintah secara demokratis sehingga mau lebih peduli dan serius dalam melaksanakan agenda penegakan HAM; desentralisasi yang tidak diikuti oleh penguatan profesionalisme birokrasi dan kontrol masyarakat di daerahdaerah potensial menimbulkan berbagai pelanggaran hak asasi manusia di tingkat lokal; budaya feodal dan korupsi menyebabkan aparat penegak hukum tidak dapat mengambil sikap tegas dalam menangani berbagai pelanggaran hak asasi manusia yang dilakukan oleh pejabat atau pemimpin masyarakat; dalam beberapa tahun terakhir, perhatian publik dan media massa lebih terfokus pada isu korupsi, terorisme, dan pemulihan ekonomi daripada penanganan kasus-kasus hak asasi manusia; ada beberapa warga dan pejabat pemerintah yang masih memegang HAM itu adalah produk budaya Barat yang individualistis dan tidak sesuai dengan budaya Indonesia; dan ketidakadilan masa lalu telah menyebabkan luka yang dalam dan dendam di antara kelompok-kelompok orang tanpa rekonsiliasi sejati. ${ }^{39}$

\section{PENUTUP}

Fakta hukum menunjukkan sejak kemerdekaan Indonesia, bahwa hak asasi manusia telah dianggap sebagai masalah kompleks baik itu yang terdapat dalam ruang setiap orang yang telah terbatas HAM nya karena berada di penjara maupun di ruang Demokrasi di arena politik. Dialog sistem hukum Indonesia dan proliferasi dan interpretasi hak asasi manusia menyoroti bahwa keselamatan kriminal hak asasi manusia berubah menjadi memutuskan kompromi, mulai dari memperkenalkan tindakan penanggulangan terhadap hak asasi manusia yang merupakan tanggung jawab manusia, untuk menyesuaikan tanggapan sesuai dengan adanya upaya tekanan Internasional. Sesudah itu, kompromi-kompromi ini tidak secara berarti mengungguli perlindungan dan kemajuan hak asasi manusia yang sebenarnya.

Pada kenyataannya, komitmen hukum dan politik tidak menjamin tindakan yang efektif. Penegakan HAM tetap menjadi masalah yang tidak ada solusi yang efektif justru menimbulkan banyak permasalahan baru. Adopsi hak asasi manusia dari pemikiran HAM barat belum tentu mengubah hubungan antara negara dan orang-orang, khususnya yang berkaitan dengan keterbukaan pemerintah tindakan kolektif yang diprakarsai oleh orang-orang dan organisasi masyarakat sipil. Didalam keterkaitan dengan Kebebasan Media dengan HAM kolektifnya ini juga memberi kebebasan bagi media untuk menyiarkan atau menerbitkan berita yang terkait dengan praktik-praktik menyimpang di tingkat pemerintah atau pelanggaran hak asasi manusia, dapat menjadi upaya penegakkan hukum praktis agar semua orang dapat meletakkan batasan dalam menginterpretasikan bahwa di dalam Hak setiap orang terdapat Hak orang lain, ini bisa menjadi peretas adanya penegakkan Hukum terhadap setiap orang secara alamiah dalam kontekstual hubungan Hukum antara orang dengan Negara dan

39 Kurniawan Kunto Yuliarso, Nunung Prajarto, "Hak Asasi Manusia (HAM) di Indonesia: Menuju Democratic Governances", Jurnal Ilmu Sosial dan Ilmu Politik, Vol. 8 (3), 2005, hlm. 291-308 
sebaliknya Negara dengan rakyat didalam suatu Negara berdaulat dan memegang sistem hukum berjalan.

Penegakan dan pemenuhan hak-hak sipil, politik, ekonomi, sosial, dan budaya di Indonesia juga banyak dipengaruhi oleh konsep relativisme hak asasi manusia, dimana dalam praktiknya, disesuainya dengan konteks budaya, agama, sosial, dan bahkan lingkungan yang ada. Hal inilah yang menyebabkan ketidaksamaan penerapan dan penegakan hukum berkaitan dengan hak asasi manusia. Masalah ini (universalisme dan relativisme) juga terus menjadi permasalahan dan perdebatan yang sampai hari ini terus terjadi, sehingga di akhir tulisan ini, penulis menyarankan bahwa meskipun Indonesia menerapkan relativisme dalam hak asasi manusia, namun norma dan standar utama yang diakui oleh negara-negara secara internasional harus dipertimbangkan ditegaskan lebih jelas.

\section{DAFTAR PUSTAKA}

\section{Buku, Artikel}

Alston, Philip. (1988). "Making Space for New Human Rights: The Case of the Right to Development", Harvard Human Rights Year Book, Vol. 3 (3), hlm. 335-357.

Arifin, Ridwan. (2017). "Revealing the Other Side of Human Rights Issue: How We Look to the Existed Various Problems", Journal of Indonesian Legal Studies, Volume 2 (1), hlm. 79-82.

Arsika, I Made Budi, Ni Gusti Ayu Dyah Satyawati, Sagung Putri M.E. Purwani. (2016). "Isu Hak Asasi Manusia dalam Penerapan Deportasi terhadap Tenaga Kerja Asing di Bali”, Pandecta Law Research Journal, Vol. 11 (1), hlm. 1-17.

Dhanhani, Shafiq and Iyanatul Islam. (2002). "Poverty, Vulnerability, and Social Protection in Period of Crisis", World Development, Vol. 30, No. 7, hlm. 1213-1214.

Donnely, Jack. (2013). Universal Human Rights in Theory and Practice. New York: Cornell University Press.

Franck, Thomas M. (1992). "The Emerging Right to Democratic Governance", Amsterdam Journal of International Law. Volume 86 Number 6, hlm. 25-62.

Freeman, Michael. (2017). Key Concepts of Human Rights. Cambridge UK: Polity Press.

Glendon, Mary Ann. (1998). "Knowing the Universal Declaration of Human Rights", Notre Dame Law Review Vol. 73 No. 5, hlm. 11-53

Hadiprayitno, Irene Istiningsih. (2010). "Defensive Enforcement: Human Rights in Indonesia", Human Rights Review, Vol. 11, hlm. 373-399.

Juwana, Hikmahanto. (2006). "Human Rights in Indonesia". In Randall Peerenboom et.al. (eds), Human Rights in Asia: A Comparative Legal Study of 12 Asians Jurisdictions, France, and the USA. New York: Routledge.

Landman, Todd. (2004). Measuring Human Rights: Principle, Practice, and Policy, Human Rights Quarterly, Vol. 26, hlm. 866-920. 
Mutua, Makau. (2002). Human Rights: A Political Cultural Critique. USA: University Pennsylvania Press.

Rohidin. (2011). "Perspektif Hukum dan HAM terhadap Eksistensi Aliran Keagamaan di Indonesia", Pandecta Law Research Journal. Vol. 6 (1), hlm. 15-25.

Roth, Kenneth. (2004). "Defending Economic, Social, and Cultural Rights: Practical Issues Faced by International Human Rights Organisations", Human Rights Quarterly 26, hlm.63-73.

Setiaji, Mukhamad Luthfan, Aminulah Ibrahim. (2017). "Kajian Hak Asasi Manusia dalam Negara the Rule of Law: Antara Hukum Progresif dan Hukum Positif", Lex Scientia Law Review, Vol.1 (1), hlm. 69-80.

Sepulveda, M. (2003). The Nature of the Obligations under the International Covenant on Economic, Social and Cultural Rights, School of Human Rights Research Series. Utrecht University, Antwerp: Intersentia.

Stahl, Frederich Julius, Ruben Alvarado (trans. and ed.). (2007). The Philosophy of Law: The Principle of Law. The Netherlands: WordBridge Publishing.

Tebbe, Nelson. (2014). "Associations and the Constitution: Four Questions about Four Freedoms", The North Carolina Law Review, Vol. 92 (3), hlm. 917-947.

Yuliarso, Kurniawan Kunto, Nunung Prajarto, (2005). "Hak Asasi Manusia (HAM) di Indonesia: Menuju Democratic Governances", Jurnal Ilmu Sosial dan Ilmu Politik, Vol. 8 (3), hlm. 291-308.

\section{Peraturan Perundang-Undangan}

Undang-Undang Dasar Negara Republik Indonesia Tahun 1945 (Amandemen IV)

Undang-Undang Nomor 39 Tahun 1999 tentang Hak Asasi Manusia

Undang-Undang Nomor 13 Tahun 2003 tentang Ketenagakerjaan

Piagam Perserikatan Bangsa-Bangsa (The UN Charter)

Deklarasasi Universal Hak Asasi Manusia (The Universal Declaration of Human Rights, UDHR)

Perjanjian Internasional tentang Hak Sipil dan Politik (International Convenant on Civil and Political Rights, ICCPR)

Perjanjian Internasional tentang Hak-Hak Ekonomi, Sosial dan Budaya (International Covenant on Economic, Social and Cultural Rights, ECOSOC)

\section{Media Daring/Internet}

Eric Posner, 2014, "The Case Againts Human Rights", The Guardian, 4 Desember 2014, diakses dari https://www.theguardian.com/news/2014/dec/04/-sp-case-againsthuman-rights

Dodi Sanjaya, 2016, "Human Rights Are (Still) Under The Threats: Government Has Not Fulfilled Its Human Rights Commitment Promises", Press Release ELSAM, Jakarta, 
ELSAM, diakses dari http://elsam.or.id/2016/12/human-rights-are-still-under-thethreats-government-has-not-fulfilled-its-human-rights-commitment-promises/

Forum Mondial des Droits de l'Homme, "Human Rights: Emerging Issues and Challenges, diakses dari http://fmdh-2014.org/en/les-droits-de-lhomme-nouvelles-questions-etdefis/

Frank La Rue, 2012, "Report of the Special Rapporteur on the Promotion and Protection of the Right to Freedom of Opinion and Expression", Human Rights Report $21^{\text {th }}$ Session, Human Rights Council the United Nations General Assembly, hlm. 11-12., diakses

http://www.ohchr.org/Documents/HRBodies/HRCouncil/RegularSession/Session20/ A-HRC-20-17_en.pdf

Franklin Delano Roosevelt, 1941, "The four freedoms", outlined in a speech on January 6, diakses dari http://maitreyasangha.org/wp-content/uploads/2012-The-FourFreedoms-UN-Charter.pdf

HS Dillon, et.al., 2015, "Civil Society Declaration Demand The Real Justice For Victims of Human Rights Violations in Indonesia", Online Press Release, the Commission for Missing Persons and Victims of Violence (Kontras), diakses dari http://www.kontras.org/eng/index.php?hal=siaran_pers\&id=279

Human Rights Watch Report 2017, https://www.hrw.org/world-report/2017/countrychapters/indonesia

Jack Britton, "Top UN Human Rights Official Completes Mission to Indonesia", Online News, February 15, 2018, diakses dari

https://thediplomat.com/2018/02/top-un-human-rights-official-completes-missionto-indonesia/

Komisi Nasional Hak Asasi Manusia (Komnas HAM), "Data Rekap Pengaduan Komnas HAM Tahun 2016", diakses dari https://www.komnasham.go.id/files/20170117data-pengaduan-tahun-2016-\$P5WKG.pdf

------------, “Data Rekap Pengaduan Komnas HAM Tahun 2018”, diakses dari https://www.komnasham.go.id/index.php/data-pengaduan/

Kristian Erdianto, 2017, "Realisasi Penegakan HAM Era Jokowi, Lain Dulu Lain Kini", KOMPAS Online, diakses dari https://nasional.kompas.com/read/2017/02/21/11113781/realisasi.penegakan.ham.er a.jokowi.lain.dulu.lain.kini

Rezki Alvionitasari, 2017, "Kontras List Human Rights Violation in Indonesia", News Online, TEMPO, diakses dari

https://en.tempo.co/read/news/2017/03/15/055856117/Kontras-Lists-Human-RightsViolations-in-Indonesia

United Nations Human Rights Office of the High http://www.ohchr.org/EN/Issues/OlderPersons/IE/Pages/InternationalStandards.aspx

United Nations, Universal Declaration of Human Rights, diakses pada http://www.un.org/en/universal-declaration-human-rights/ 
Ridwan Arifin, Rasdi, Riska Alkadri Tinjauan Atas Permasalahan Penegakan Hukum dan Pemenuhan Hak Dalam Konteks Universalime dan Relativisme Hak Asasi Manusia di

[Online] http://www.humanrights.com/voices-for-human-rights/human-rights-challenges.html 